情報管理 Vol. 33 No. 5 Aug. 1990

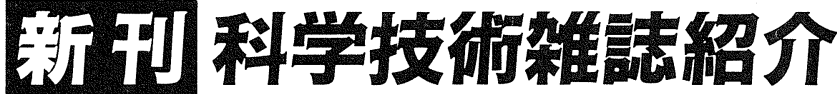

\section{Structural Chemistry}

$(\mathrm{T} 880 \mathrm{~A})$

発行所：VCH Publishers, Inc., (New York)

編集者：I. Hargittai (Hungarian Academy of Science \& Eoetvoes University, Hungary), A. Greemberg (New Jersey Institute of Chemistry, USA)

使用言語：英語

刊行周期：隔月刊

創刊年月：1990 年 1 月

講 読 料：95ドル/年

本誌は最近の文献における構造決定・エネルギ 一論・応用面の不自然な分離を克服して他の化学 分野への架け橋になることを目的とした国際誌で あり, 副標題「An International Journal Concerned with Energy, Structure, and Their Relationships to Chemical, Physical, Biological Properties」をもつ。

主題分野は, X 線, NMR などの各種分光による 実験構造解析法, 実験的熱化学および光電子スぺ クトロスコピーのような他の関連技法を含んでい る。

記事内容は, 原著論文, 総説, 速報, 書評など であり，この他に会議, データベースなどのトピ ックス欄がある。

創刊号には理論化学 5 件, 熱量測定 1 件, 分光 学 2 件, 無機化学 2 件, 有機化学 4 件, 生化学 3 件, 計 17 件の抄録付きの原著論文と書評 8 件が 掲載されている。総頁数 150 頁。

日本から, 長岡技術科学大学の朽津耕三教授が 編集委員に参加している。

\section{Seminars in CELL BIOLOGY}

(T944A)

発行所：W. B. Saunders Company

(Philadelphia)
編集者：Alan Colman (University of Birmingham)

使用言語：英語

刊行周期：隔月刊

創刊年月：1990 年 2 月

購 読 料：個人 95 ドル

図書館 140 ドル

学生 80 ドル

細胞生物学の分野は広範に渡るため報文の数も 増加の一途をたどり，その結果研究者が研究テー マ外の分野に追いついて行くのは容易ではない。 本誌はこの現状を踏ま之，専門外の研究者が発展 的な分野における研究の展開を系統的な知識とし て得ることを目的に創刊されたレビュー誌であ る。

国際的権威から成る編集委員が主題とその適切 な編者を厳選。研究が完了して $3 ， 4$ か月以内の 新鮮な話題が選ばれ，その分野において認められ た学者がすでに一般的とされた内容を簡明に実例 を示して執筆しているので, 研究者から学生まで 幅広い読者が想定されている。

創刊号は， molecular chaperone（分子付添い） をテーマとして取り上げ，その提唱者による概説 と，蛋白質の集合や折りたたみを伴う生体膜輸送 について 8 報の総説を掲載。以後, 細胞運動力, ショウジョウバエのパターン形成，筋と非筋の $\mathrm{Ca}^{2+}$ ホメオスタシス，膜と細胞骨格の相互作用等 のテーマが予告されている。

Antiviral Chemistry \& Chemotherapy

(T946A)

発行所: Blackwell Scientific Publications Ltd. (Oxford, UK)

編集者：J. Oxford（London Hospital Medical College, UK)

使用言語：英語 
刊行周期：隔月刊 創刊年月：1990 年

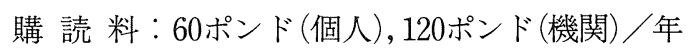
エイズのように新しいウイルス感染症がある一 方で，インフルエンザのように古くからの感染症 についても未解決であるが，本誌は，新しい安全 で有効な抗ウイルス薬の開発やウイルス疾患の治 療のよりよい理解の中心となり，アイデアを生み 出し, 情報を交換する場として, 創刊された。 抗ウイルス化合物の生化学, 作用機序, 化学, 薬理, ウイルス学に関する重要で独自な研究結果 を扱う。また, 高品質の臨床文献と抗ウイルス研
究に関連した分子生物学の論文も掲載する。但し， 一般的なウイルス学やワクチンに関する研究は対 象としていない。

原著論文，総説，短報，コメント，レターを揭 載する。原著論文には 250 words 以下のサマリー が付いている。

創刊号には, ミニレビュー 1 報, 原著論文 9 報, レター 1 報を揭載している。エイズウイルス (HIV) に対する抗ウイルス薬の研究が半分を占 め，他はへルペスウイルス，ピコルナウイルス， コロナウイルス，レトロウイルスを対象とした， 合成を含めた基礎研究が発表されている。 